\title{
Research on Network Engineering Professional Practice Teaching Reform and Innovation in Application-oriented Undergraduate Universities
}

\author{
Chang-jian GUO \\ Department of Computer Science and Technology \\ Hefei University \\ Hefei, China \\ Guocj1965@163.com
}

\author{
Zheng-mao LI \\ Department of Computer Science and Technology \\ Hefei University \\ Hefei, China \\ lzm424@yeah.net
}

\begin{abstract}
This article explores the network engineering specialty practice teaching mode and puts forward a reasonable modular practice teaching mode, so as to build a more perfect applied undergraduate network engineering practice teaching system, which can provide theoretical basis and operational platform for improving the teaching quality and cultivating higher applied talents with international cooperation ability.
\end{abstract}

Keywords-Network engineering;

Practice

teaching; Modularization

\section{INTRODUCTION}

The network engineering major is a newly established undergraduate major outside the Ministry of Education Professional Catalogue established after 2000. The professional development time is short, and the related teaching system lacks a referenceable goal. In addition, the application orientation of the applied-type undergraduate colleges is mainly based on the "application type", while the practical teaching mainly aims at cultivating the students' application ability, which is also an important link in the teaching of higher education. It improves the overall quality of students and cultivates students' sense of innovation. And the ability to innovate, as well as make students become an applied talent has a special role. As early as in 2007, the Ministry of Education emphasized in the "undergraduate teaching quality project" that the practical teaching of engineering majors should not be lower than $25 \%$ of the total class hours. Due to the special nature of the teaching of network engineering, the proportion of practical teaching in the whole teaching process is even greater. Its basic task is to train students to use basic theories, knowledge, and skills comprehensively to train students in their ability to analyze and solve practical problems. To improve students' awareness of innovation, practical ability and creativity; therefore, it is more urgent to explore a new type of practical teaching model for local colleges that focus on applied education. Therefore, how to reform the traditional practice teaching mode and improve the quality of practical teaching to adapt to the rapid development of higher education has become an important topic in the current application-oriented undergraduate education reform. Therefore, it is very important to develop a practice teaching system for network engineering. Necessary and meaningful [1].

\section{The CuRRENT SituATION AND EXISTING PROBLEMS OF PRACTICAL TEACHING}

At present, most of the network engineering majors in universities or colleges still use the traditional practice teaching model, and the experimental teaching link is mainly based on the verification of theoretical knowledge. The topics of curriculum design and graduation design mainly come from books, networks, or "take it for granted" ; students are hard to get into practice. The lack of innovation has greatly affected the realization of the application-oriented personnel training objectives. The problems in practical teaching can be mainly reflected in the following aspects:

\section{A. The imperfect practice teaching system}

At present, the applied-type undergraduate colleges generally have the personnel training model and the curriculum system for the old-fashioned undergraduate colleges. The convergence in practice teaching is particularly serious and the theory is light practice. As a result, the undergraduate talents cultivated in each school have poor practical ability and are difficult to obtain. The employer's favor. Therefore, the application of undergraduate talent characteristics, through the professional orientation and curriculum system construction to build their own application-oriented undergraduate talents practical teaching system is an urgent problem to be studied and solved for all application-oriented undergraduate colleges and universities.

\section{B. Weak practice teaching}

Today's university education has a large number of students and a lack of practical environment. Most of them are mainly boring theoretical education. There are fewer opportunities for students to participate in practice, coupled with the lack of necessary communication and communication with companies, and the most important practice teaching. The graduation design of the link is also basically a traditional model. Most students do not contact with the enterprise and the actual during the entire design process, which greatly reduces the students' ability to innovate and hands-on, and causes the students to lose their autonomy and passion for learning. The students lack practical application skills and cannot meet the actual needs of the enterprises, making it difficult for students 
to find employment in the future and making it difficult to adapt to society directly.

On the other hand, most of the teachers in colleges and universities rarely have experience in corporate work, that is, they generally lack practical experience. Therefore, these teachers have very few complete and accurate understandings of the application and practice of emerging disciplines, and thus it is difficult to have a comprehensive guide for students' practical work. This is an important reason why the quality of practical teaching in our universities is not high.

\section{Practice teaching and employment out of touch}

At present, the focus of higher education is still on the basic knowledge and professional knowledge, and the systematic training and training of the professional ideas, concepts, knowledge, methods, and professional skills required for the employment of college graduates are insufficient. The lack of professional knowledge leads to insufficient "employment ability." In contrast, the German University of Applied Sciences is practice-oriented, with particular emphasis on the cultivation of students' practical abilities. The characteristics of practical teaching are to highlight the simultaneous development of practical teaching and socio-economic development, to keep pace with the progress of science and technology, and to closely integrate with the production of enterprises. Most of the experimental projects, curriculum design and graduation design in school practical teaching come from factories and enterprises. They have strong pertinence and reality, which is the so-called "true" teaching, that is, the contents of practical teaching are taken from the reality of society and need to be solved. The real subject. In addition, the German modular teaching reform has solved the phenomenon of mutual independence among the courses. Classroom teaching closely links with the actual situation of the company. Its curriculum and content are more emphasis on the application, and the two teaching links between theory and practice are closely combined. The organic combination of teaching content and the reform of teaching methods and teaching methods cultivate students' comprehensive quality and application ability.

\section{PRACTICE TEACHING REFORM PLAN}

Based on the investigation of the professional construction of network engineering for undergraduate colleges at home and abroad, the main objective is to cultivate the demand for applied talents, analyze the problems existing in the practice teaching process of China's applied undergraduate colleges, and aim at the practical teaching model of domestic applied undergraduates. Disadvantages, the use of modular ideas on the practical teaching system [2], thus reforming the practical teaching system, the specific content are:

\section{A. Cultivating clear goals and integrating professional teaching content}

Taking service as its tenet, employment as the guide, and integrating production, teaching and research are important methods for the training of applied talents. The specific approach is: based on the work position, integrate professional teaching content; based on the work position is to measure the practicality of professional teaching content from the students' way out. The specific work to be done [3]:

- Conduct social research on network engineering teaching and comparative research at home and abroad.

- According to the needs of network engineering professional and technical fields need to set and adjust the professional (direction), highlighting the application and practicality.

- Correctly handle the relationship between knowledge, ability and quality, and adapt to social needs as the goal, design a talent training program that fosters the application of professional and technical skills.

- Planning and construction of teaching staff, experiments, training bases and teaching materials.

\section{B. Focusing on the requirements of training applied talents and building a multi-dimensional integrated practice teaching system}

Practical teaching is the deepening and development of theoretical teaching, and it is also an expanding platform for quality education. In view of the disadvantages of the traditional undergraduate education: the disjoint between theory and practice, the disconnect between school and society, and the disconnection between unity and individual needs, according to the characteristics of computer science in applied undergraduate colleges, the idea of building an open practice teaching system is proposed. First, the practice teaching reform must first integrate the teaching content, find out the important knowledge points of the course, determine what the students must master, and delete some non-focus content. Consolidate the same or similar subjects in large classes to avoid subdivision or duplication of courses. In order to ensure that the latest information is integrated into the curriculum, second, all practical teaching links and all other activities that students participate in outside of the theoretical teaching should be included in the practical teaching area, so that all practical links and extracurricular activities that students participate in the school become organically linked teaching system. In this open practice teaching system, it includes both traditional experiments, practical training, and internships, as well as competitions of various disciplines. A mainline and three-level practice teaching system was established. The practical teaching system consists of three levels of training programs: basic skills training, special ability training, and technical application ability training. Experiments, practical training, and practice correspond to the three levels of the practical teaching system. Practice training programs are divided into: practice guidance. The provisions of the book require that $\rightarrow$ part of the requirements according to the provisions of the practice guide $\rightarrow$ set the target to design the practice of the project to complete the training of the three stages [4-5]. 
The following figure 1 is The Block Diagram of "Three-Segment Integration" Practical Teaching System

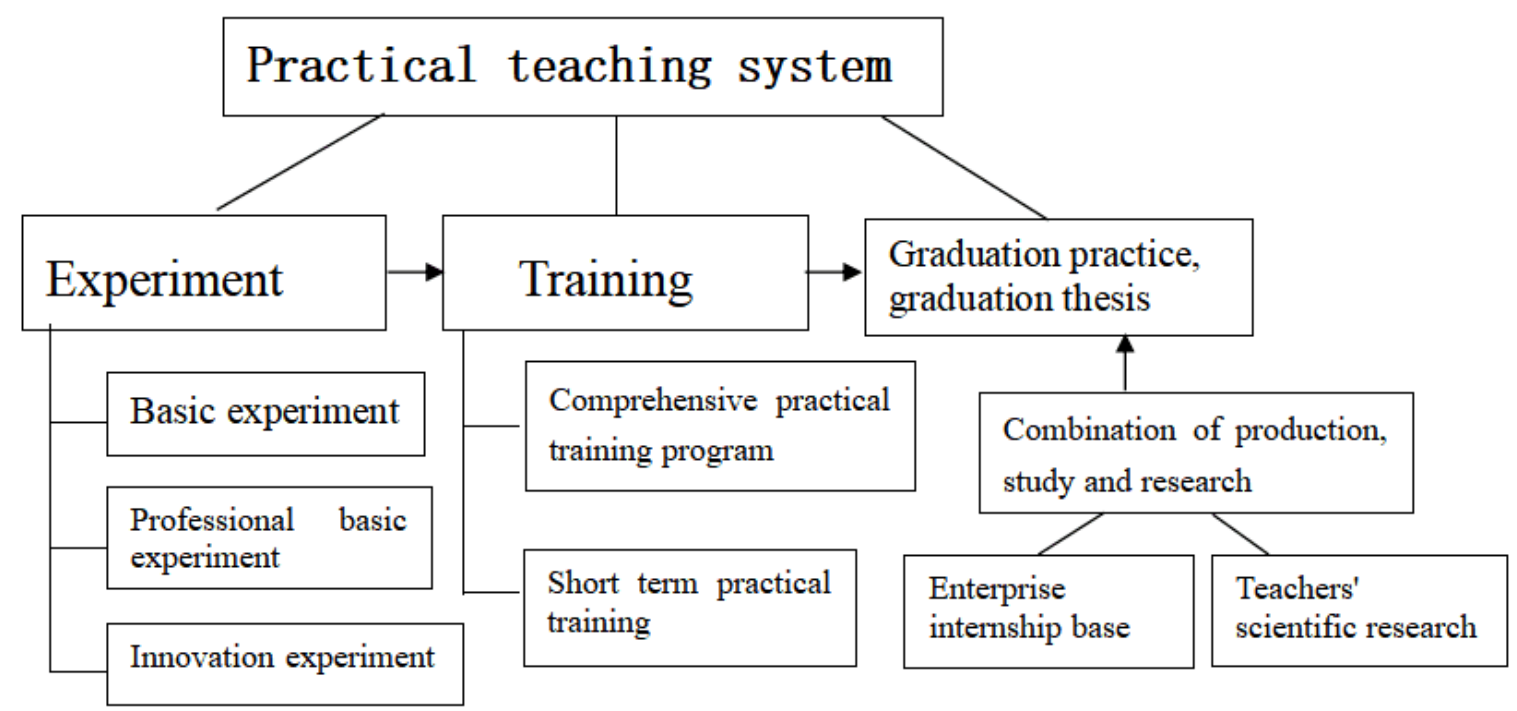

Fig. 1 The Block Diagram of "Three-Segment Integration" Practical Teaching System

\section{Research and construction of practice teaching platform}

The practical teaching platform is the key to practical teaching, and different construction methods can be used for different platforms [6]. The specific practice teaching platform research and construction are as follows:

- Experimental module: Each experimental course is planned by the person in charge of the course, formulates detailed experimental teaching syllabus and experimental instruction book, organizes and standardizes the experimental topics, and defines the knowledge points emphasized by each topic. Establish innovative laboratories, actively organize and attract students to participate in scientific and technological innovation activities, establish innovation teams, adopt self-selected topics, guide teachers to specify topics, or provide enterprises with topics, and then enter the open laboratories after validation. We will formulate and improve the rules for open laboratories, and stipulate its operating mechanism and operating mode. In this module, the experiment can be decomposed into a number of individual ability, unit ability, and comprehensive ability. The main goal of this experimental teaching is to complete the training of one or several single items and unit ability training. Experimental teaching is done in the course of the corresponding course teaching in the way of learning and doing.

- Training module: Practical training is based on the completion of single-item and unit-ability training. It focuses on the training of students and aims to cultivate students' comprehensive ability. It includes comprehensive training and short-term training. According to the talent demand forecast and student interest, employment will be trained in the professional direction, and enter the integrated training module; this stage is divided into several modules according to the professional direction, for example, under the "Computer Science and Technology" professional, divided into software engineering, embedded System engineering and network engineering three modules. According to the professional overall training objectives, each module has formulated its own teaching objectives. Each module has designated the responsible person of the module to make overall planning and formulate a comprehensive project training outline. Project-driven, group approach. The training topics can come from various channels such as enterprises and teachers' research projects. Students can independently complete the actual combat process from market research, project design, and implementation, write project design papers, and use the form of defense in other students. In front of the teacher, the project shows the progress of the project and solutions; prompts students to integrate the previously learned knowledge, improve their analytical and hands-on ability to solve problems, and form a team spirit in the project development process. All practical training requirements are:

a) Design comprehensive training projects based on the typical comprehensive technical task work process;

b) The content of practical training should be integrated into the corresponding content of the application technology capabilities necessary for the professional field;

c) Practical training should generally be combined with productive (or simulation) training and conducted in a task-driven manner;

d) Practical training is generally completed in the on-campus training center or in the enterprise.

- Graduation Internship / Graduation Design Module: Graduation Internship / Graduation Design is an important part of higher education. It is the continuation, 
deepening, supplementation, and testing of other teaching links. It is also the key point in the practical teaching system. In order to do a good job in graduation practice/graduation design practice, graduation internships/graduation design appoint the responsible person for overall planning, formulate corresponding systems, and construct an information platform for graduation internships and graduation design work to effectively monitor and manage the entire process. . In the framework of the practice teaching system, a variety of forms of graduation design patterns are established. The contents of the graduation project can be extended to the contents of the training phase. The following basic forms are tentatively conceived:

a) Collaborative: The Department establishes long-term practice bases. Students can directly go to practice bases to internships. Students can enter companies and introduce practical issues from companies. Engineers can propose design topics based on actual production and graduate design.

b) Scientific research type: The topic of graduation design comes from teachers' research projects. It allows students to assist teachers in completing their scientific research work. It also improves students' practical ability while completing graduation design.

c) Entries: Encourage students to participate in various scientific and technological innovations and design competitions. The topic of student graduation design may be related to the content of the entries, or directly to improve and expand the entries as a graduation design task

Students who graduated from the practice base may adopt the "double-tutoring system", which enables students to acquire both system knowledge and application ability at the same time. This makes them a solid foundation for applied talent [7-8].

\section{MAIN FEATURES}

Based on the successful experience and modularization concept of the German applied talents training model, we pointed out some problems that need to be solved in the practical teaching of network engineering majors in applied universities, and explored a new practical teaching model. The main features of this practical teaching model are reflected in the following three aspects:

- In terms of research methods, it analyzes the outstanding problems in the teaching mode of domestic applied universities and introduces the German "modular" teaching philosophy. This paper proposes a concept for the practical teaching system of network majors in China's applied undergraduate colleges.

- In the application practice, focusing on a specific topic, we focus on linking the students' professional knowledge at each stage of the study, and the content of the practical teaching system is constantly updated and changed along with the needs of the enterprise. The introduction of the teaching model has strengthened students' innovative thinking, the cultivation of practical abilities enables students to quickly apply what they have learned to practice as soon as they go to work.

- The research on the talent training model based on the professional application ability as the main line and the three-level practice teaching is scientific, pertinent, and practical, and is consistent with the law of application-oriented undergraduate education and teaching.

\section{CONCLUSION}

This article specifically analyzes the deficiencies in practical teaching of applied universities in China, and puts forward some specific research and reform methods. The results of the research will correctly target the application of undergraduate education and how to develop professional training programs for undergraduate education. It has important reference value and has certain guiding significance for the research and practice of practice teaching reform in domestic applied universities.

\section{ACKNOWLEDGEMENT}

This paper is supported by Higher Education Quality Engineering of Anhui Province (2015ckjh061, 2015zy054, 2017mooc318), Higher Education Revitalization Plan Major Teaching Reform Project of Anhui Province (2015zdjy141), Teaching Team of Anhui Province (2016jxtd101), Outstanding Talent Education Training Plan of Anhui Province (2015zjjh026).

\section{REFERENCES}

[1] Zeng Jin. Analysis of the Present Situation of Network Engineering Development [J].Computer Aid 2017(10)32-34.

[2] Zhou Jun. Discussion on Modular Teaching Method of Computer Specialty [J].Journal of Liaoning Education Administration College, 2008, 24(2):44-46.

[3] Jin Yu, Zhao Hongwu, Gu Jinguang. Discussion on Construction of Practice Teaching System for Network Engineering [J].Computer Education, 2011(2):100-103.K.

[4] Chen Weihong, Xiao Weichu et al. Construction of practical network education teaching system for applied talents training [J].China Electric Power Education, 2010. (36).

[5] Shi Xiaoqiu. The Construction of Network Engineering Practice Curriculum System for Applied Talent Cultivation[J].University of China Education, 2008(12):35-37

[6] Sun Lijuan, Zhai Yongping, Huang Yimei. Research on the Construction and Teaching Methods of Network Engineering Practice Teaching Resources [J].Computer Education, 2015(22):112-114.

[7] Huang Haibo, Yang Sen. Research on Practice Teaching System of Network Engineering [J]. Office Automation: An Academic Edition, 2013(11):28-29.

[8] Liu Yugang. Research on the Cultivation of Practical Innovation Ability Based on Projects $[\mathrm{J}]$.Contemporary Education Practice and Teaching Research: Electronic Journal, 2017(5):43-43. 